\title{
Synthesis of Six-Arm Star Polymer by Nitroxide-Mediated "Living" Radical Polymerization
}

\author{
Yozo MIURA ${ }^{\dagger}$ and Yuji YosHIDA \\ Department of Applied Chemistry, Graduate School of Engineering, Osaka City University, \\ Sumiyoshi-ku, Osaka 558-8585, Japan
}

(Received May 7, 2002; Accepted August 6, 2002)

\begin{abstract}
A dendritic multifunctional initiator with 6 TEMPO-based alkoxyamine moieties was prepared from 4-bromophenylethylbenzene in 7 steps and 6-arm star polymers were prepared by the radical polymerization of styrene (St) using the dendritic alkoxyamine as an initiator. The St polymerizations were carried out at $120^{\circ} \mathrm{C}$ using the dendritic alkoxyamine concentrations of $5.0,12.8$, and $18.8 \mathrm{mmol} \mathrm{L}^{-1}$. When the alkoxyamine concentration was $5.0 \mathrm{mmol} \mathrm{L}^{-1}$, the polydispersity indexes of the resulting star polymers increased with conversion and that of the star polymer at $72 \%$ conversion was 1.59. On the other hand, when the alkoxyamine concentrations were 12.8 and $18.8 \mathrm{mmol} \mathrm{L}^{-1}$, the polymerization was well controlled to give star polymers with a low polydispersity index even at high conversion. The side reactions disturbing the "living" fashion were discussed on the basis of the SEC elution curves of the star polymers obtained.

KEY WORDS Star Polymer / Living Radical Polymerization / Nitroxide / Alkoxyamine / Polydispersity Index /
\end{abstract}

Since nitroxide-mediated "living" radical polymerization provides well-defined polymers with a low polydispersity index, this technique has attracted much attention from the view of points of both polymer chemistry and polymer industry. ${ }^{1-4}$ In this polymerization system the propagating radical chains are capped by nitroxides, giving deactivated (dormant) species, and the resultant dormant species are reactivated via the homolytic $\mathrm{C}-\mathrm{O}$ bond dissociation at high temperature (usually above $110^{\circ} \mathrm{C}$ ) to give propagating radical chain and nitroxide. Since the equilibrium for the $\mathrm{C}-\mathrm{O}$ bond dissociation and reformation shifts to the bond formation side, most of the propagating radical chains exist as the dormant species, leading to a very low concentration of the propagating radical compared with the conventional radical polymerization system. This characteristic of the nitroxide-mediated "living" radical polymerization is favorable to syntheses of well-defined star polymers because intermolecular and intramolecular coupling reactions between the propagating radicals must be suppressed. In a previous paper we reported the syntheses of well-defined 3-arm star polymers with a low polydispersity index using 1,3,5-tris(alkoxyamino)benzenes as an initiator. ${ }^{5}$ Since the 1,3,5-tris(alkoxyamino)benzenes have no chemically labile bonds, the resultant star polymers are very stable under the strongly acidic or basic conditions. This characteristic makes a wide variety of applications of the resulting star polymers possible. In a continuing synthetic study of star polymers, we synthesized 6-arm star polymers using Star-6, a dendritic TEMPO-based alkoxyamine. Herein we wish to report the synthesis of Star-6 and the TEMPO-mediated "living" radical polymerization of styrene (St) initiated with Star-6 giving a well defined 6-arm star polymer.

Although many star polymers have so far been prepared by the nitroxide-mediated polymerization, ${ }^{4}$ ATRP, ${ }^{6}$ and RAFT methods, ${ }^{7}$ most were prepared by the ATRP method because the ATRP method has the advantages that a wide variety of monomers are applicable and polyhalogeno compounds as an initiator are readily obtained. However, the ATRP method yields "transition metal contaminated" polymers, different from the nitroxide-mediated or RAFT method. The synthetic approachs to star polymers by the nitroxidemediated "living" radical method are classified by two methods, as well as the ATRP or RAFT method: the "core-first" method and "arm-first" method. The armfirst method ${ }^{8}$ is an easy approach to star polymers compared with the core-first method, but doesn't give structurally regular (arm-number constant) star polymers. On the other hand, the core-first method, ${ }^{5,9-11}$ requires much effort for the syntheses of multifunctional alkoxyamines. Since our aim is in the preparation of structurally well-defined star polymers, the 6-arm star polymer was prepared by the core-first method. Furthermore, since Star-6 has no chemically labile bonds, as well as the previous 3 -functional alkoxyamines, ${ }^{5}$ the resulting St-based star polymers are expected to be stable under the acidic or basic conditions.

${ }^{\dagger}$ To whom correspondence should be addressed 


\section{EXPERIMENTAL}

\section{Measurements}

${ }^{1} \mathrm{H}$ NMR spectra were recorded on a JEOL $\alpha 400$ NMR spectrometer $(400 \mathrm{MHz})$ using TMS as the internal standard. High resolution HAB mass spectra (HRHABMS) were obtained with a JEOL JMSAX500 spectrometer with a direct method. Size exclusion chromatography (SEC) measurements were carried out with a Tosoh GPC 8020 series using TSK $_{\text {gel }}$ $\mathrm{G} 5000 \mathrm{H}_{\mathrm{HR}}$, Multiporeh $\mathrm{XL}-\mathrm{M}$, and $\mathrm{GMH}_{\mathrm{HR}}-\mathrm{L}$ columns calibrated with the polystyrene standards, eluting with THF at $40^{\circ} \mathrm{C}$. Detection was made with a Tosoh refractive index detector RI8020. Preparative high performance liquid chromatography (HPLC) was carried out with a Japan Analytical Industry LC-908 recycling HPLC instrument, using $\mathrm{CHCl}_{3}$ as the eluant. The light scattering measurements were carried out in THF at $30^{\circ} \mathrm{C}$ with an Otsuka Electronics DLS-700 dynamic light scattering spectrophotometer over the angular range between $30-150^{\circ} \mathrm{C}$, using unpolarized light of wavelength $632.8 \mathrm{~nm}$.

\section{Materials}

2,2,6,6-Tetramethylpiperidinyl- $N$-oxyl (TEMPO) was commercially available. Di-tert-butyl diperoxyoxalate (DBDP) was obtained by the reported method. ${ }^{12}$ 1-(4-Hydroxymethylphenyl)-1-(2,2,6,6-tetramethyl-1-piperidinyloxyl) ethane (3) was prepared by our previous procedure. ${ }^{13}$ Column chromatographic purification was carried out on silica gel $60 \mathrm{~N}$ (Kanto Chemical Co., Inc.).

1-(4-Bromomethylphenyl)-1-(2,2,6,6-tetramethyl-1piperidinyloxyl)ethane (4). A solution of $3(2.16 \mathrm{~g}$, $7.41 \mathrm{mmol})$ in dry ether $(150 \mathrm{~mL})$ was cooled to $-70^{\circ} \mathrm{C}$, and $\mathrm{PBr}_{3}(0.48 \mathrm{~mL}, 5.2 \mathrm{mmol})$ was added dropwise with stirring. After the addition, the solution was raised to room temperature and stirring was continued for $2 \mathrm{~h}$. The mixture was again cooled to $-70^{\circ} \mathrm{C}$, and water was added to decompose the unreacted $\mathrm{PBr}_{3}$. The mixture was then extracted with ether, dried over anhydrous $\mathrm{MgSO}_{4}$, and evaporated under reduced pressure. The residue was chromatographed on silica gel with benzene, and recrystallization from methanol gave colorless needles in $67 \%$ yield $(1.76 \mathrm{~g})$. Mp 51-52 ${ }^{\circ} \mathrm{C},{ }^{1} \mathrm{H}$ NMR $\left(400 \mathrm{MHz}\right.$, in $\left.\mathrm{CDCl}_{3}\right): \delta 0.66$, $1.02,1.16,1.26$ (each s, $\mathrm{CH}_{3}, 12 \mathrm{H}$ ), 1.26-1.37 (br m, $\left.\left(\mathrm{CH}_{2}\right)_{3}, 6 \mathrm{H}\right), 1.46\left(\mathrm{~d}, J=6.8 \mathrm{~Hz}, \mathrm{CHCH}_{3}, 3 \mathrm{H}\right), 4.50$ (s, benzylic, $2 \mathrm{H}), 4.78$ (q, $\left.J=6.8 \mathrm{~Hz}, \mathrm{CHCH}_{3}, 1 \mathrm{H}\right)$, $7.29(\mathrm{~d}, J=8.3 \mathrm{~Hz}$, aromatic, $2 \mathrm{H}), 7.33(\mathrm{~d}, J=8.3 \mathrm{~Hz}$, aromatic, $2 \mathrm{H})$.

[G-1]-OH. A mixture of $4(1.00 \mathrm{~g}, 2.82 \mathrm{mmol})$, 3,5-dihydroxybenzyl alcohol $(0.190 \mathrm{~g}, 1.36 \mathrm{mmol}), 18$ crown-6 $(35 \mathrm{mg}, 0.13 \mathrm{mmol})$, and $\mathrm{K}_{2} \mathrm{CO}_{3}(0.57 \mathrm{~g})$ in acetone $(15 \mathrm{~mL})$ was gently refluxed for $24 \mathrm{~h}$ under nitrogen. After filtration, the filtrate was evaporated under reduced pressure, and the residue was chromatographed on silica gel with $1: 2$ ethyl acetatehexane to give [G-1]-OH as a colorless oil in $67 \%$ yield $(0.683 \mathrm{~g}) .{ }^{1} \mathrm{H} \mathrm{NMR}\left(400 \mathrm{MHz}\right.$, in $\left.\mathrm{CDCl}_{3}\right): \delta 0.68$, $1.03,1.16$, and 1.29 (each s, $\left.\mathrm{CH}_{3}, 24 \mathrm{H}\right), 1.26-1.37$ (br $\left.\mathrm{m},\left(\mathrm{CH}_{2}\right)_{3}, 12 \mathrm{H}\right), 1.47\left(\mathrm{~d}, J=6.8 \mathrm{~Hz}, \mathrm{CHCH}_{3}, 6 \mathrm{H}\right)$, $1.81(\mathrm{~s}, \mathrm{OH}, 1 \mathrm{H}), 4.61\left(\mathrm{~s}, \mathrm{CH}_{2} \mathrm{OH}, 2 \mathrm{H}\right), 4.79(\mathrm{q}, J=$ $\left.6.8 \mathrm{~Hz}, \mathrm{CHCH}_{3}, 2 \mathrm{H}\right), 5.00$ (s, benzylic, $\left.4 \mathrm{H}\right), 6.54(\mathrm{t}$, $J=2.4 \mathrm{~Hz}$, aromatic, $1 \mathrm{H}), 6.62(\mathrm{~d}, J=2.4 \mathrm{~Hz}$, aromatic, $2 \mathrm{H}$ ), 7.32 and 7.35 (each d, $J=8.5 \mathrm{~Hz}$, aromatic, $8 \mathrm{H}$ ). HRHABMS: calcd for $\mathrm{C}_{43} \mathrm{H}_{63} \mathrm{~N}_{2} \mathrm{O}_{5}$ [M $+\mathrm{H}]^{+}$687.4737, found 687.4738. Anal. Calcd for $\mathrm{C}_{43} \mathrm{H}_{62} \mathrm{~N}_{2} \mathrm{O}_{5}$ : C, 75.18\%; H, 9.10\%; N, 4.08\%. Found: C, $76.05 \%$; H, 9.51\%; N, 4.07\%.

[G-1]-Br. [G-1]-OH $(1.34 \mathrm{~g}, 1.95 \mathrm{mmol})$ was dissolved in anhydrous THF $(15 \mathrm{~mL})$ and heated to $60^{\circ} \mathrm{C}$ with stirring under nitrogen. After $\mathrm{CBr}_{4}(1.29 \mathrm{~g}$, $3.90 \mathrm{mmol})$ was added, $\mathrm{PPh}_{3}(1.00 \mathrm{~g}, 3.81 \mathrm{mmol})$ was added in four portions over $2 \mathrm{~h}$, and the resulting mixture was stirred at the same temperature for $12 \mathrm{~h}$. After cooling, water was added and the reaction mixture was extracted with $\mathrm{CH}_{2} \mathrm{Cl}_{2}$. The $\mathrm{CH}_{2} \mathrm{Cl}_{2}$ layer was dried over anhydrous $\mathrm{MgSO}_{4}$ and evaporated under reduced pressure. The residue was then chromatographed on silica gel with benzene, giving a colorless oil of [G1]-Br in $57 \%$ yield $(0.83 \mathrm{~g}) .{ }^{1} \mathrm{H}$ NMR $(400 \mathrm{MHz}$, in $\mathrm{CDCl}_{3}$ ): $\delta 0.68,1.02,1.16,1.29\left(\right.$ each s, $\left.\mathrm{CH}_{3}, 24 \mathrm{H}\right)$, $1.26-1.37$ (br m, $\left.\left(\mathrm{CH}_{2}\right)_{3}, 12 \mathrm{H}\right), 1.47(\mathrm{~d}, J=6.8 \mathrm{~Hz}$, $\left.\mathrm{CHCH}_{3}, 6 \mathrm{H}\right), 4.40$ (s, $\left.\mathrm{CH}_{2} \mathrm{Br}, 2 \mathrm{H}\right), 4.79$ (q, $J=6.8 \mathrm{~Hz}$, $\left.\mathrm{CHCH}_{3}, 2 \mathrm{H}\right), 4.99$ (s, benzylic, $\left.4 \mathrm{H}\right), 6.56$ (t, $J=$ $2.0 \mathrm{~Hz}$, aromatic, $1 \mathrm{H}), 6.63(\mathrm{~d}, J=2.0 \mathrm{~Hz}$, aromatic, $2 \mathrm{H}$ ), 7.33 and 7.35 (each d, $J=8.5 \mathrm{~Hz}$, aromatic, $8 \mathrm{H}$ ).

Star-6. A mixture of [G-1]-Br $(1.00 \mathrm{~g}, 1.33$ mmol), 1,3,5-benzenetriol ( $42 \mathrm{mg}, 0.33 \mathrm{mmol}), \mathrm{K}_{2} \mathrm{CO}_{3}$ $(0.32 \mathrm{~g})$, and 18 -crown-6 $(70 \mathrm{mg}, 0.26 \mathrm{mmol})$ in acetone $(30 \mathrm{~mL})$ was heated at $40^{\circ} \mathrm{C}$ for $48 \mathrm{~h}$ with stirring under nitrogen. After filtration, the filtrate was evaporated under reduced pressure, and the residue was chromatographed on silica gel with $1: 4$ ethyl acetatehexane. Further purification on a preparative recycling HPLC gave star-6 as a colorless oil in 16\% yield $(111 \mathrm{mg}) .{ }^{1} \mathrm{H}$ NMR $\left(400 \mathrm{MHz}\right.$, in $\left.\mathrm{CDCl}_{3}\right): \delta 0.67$, $1.02,1.16,1.29$ (each s, $\mathrm{CH}_{3}, 72 \mathrm{H}$ ), $1.25-1.36$ (br m, $\left.\left(\mathrm{CH}_{2}\right)_{3}, 36 \mathrm{H}\right), 1.47\left(\mathrm{~d}, J=6.8 \mathrm{~Hz}, \mathrm{CHCH}_{3}, 18 \mathrm{H}\right)$, 4.79 (q, $J=6.8 \mathrm{~Hz}, \mathrm{CHCH}_{3}, 6 \mathrm{H}$ ), 4.93 (s, benzylic, $6 \mathrm{H}), 5.00(\mathrm{~s}$, benzylic, $12 \mathrm{H}), 6.26(\mathrm{~s}$, aromatic, $3 \mathrm{H})$, $6.56(\mathrm{t}, J=2.0 \mathrm{~Hz}$, aromatic, $3 \mathrm{H}), 6.68(\mathrm{~d}, J=2.0 \mathrm{~Hz}$, aromatic, $6 \mathrm{H}$ ), 7.32 and 7.35 (each d, $J=7.8 \mathrm{~Hz}$, aromatic, $24 \mathrm{H}$ ). HRHABMS: calcd for $\mathrm{C}_{135} \mathrm{H}_{187} \mathrm{~N}_{6} \mathrm{O}_{15}$ 


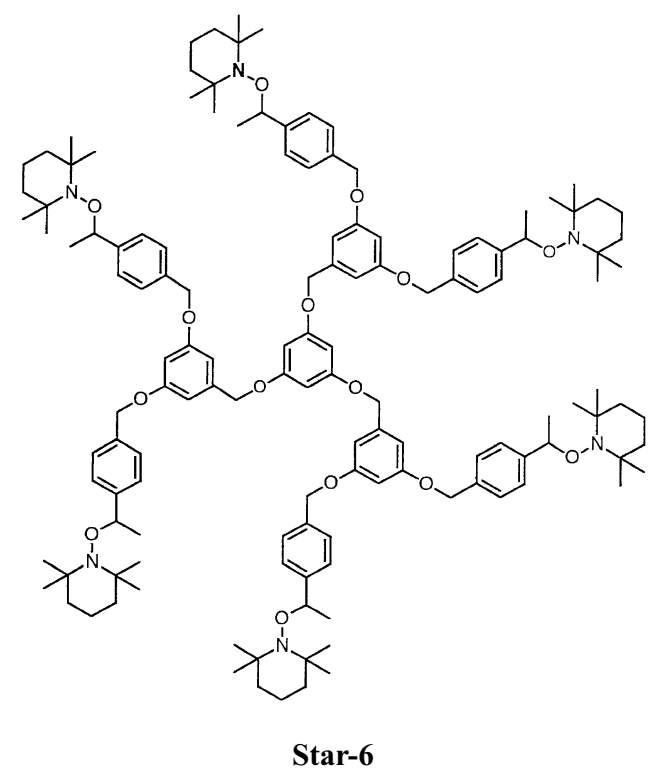

$[\mathrm{M}+\mathrm{H}]^{+}$2133.4088, found 2133.3984. Anal. Calcd for $\mathrm{C}_{135} \mathrm{H}_{186} \mathrm{~N}_{6} \mathrm{O}_{15}: \mathrm{C}, 76.02 \% ; \mathrm{H}, 8.79 \%$; N, 3.94\%. Found: C, $74.72 \%$; H, 8.28\%; N, 3.92\%.

\section{Polymerization}

A styrene solution $(0.50 \mathrm{~mL}, 4.4 \mathrm{mmol})$ of Star-6 $\left(5.0 \mathrm{mmol} \mathrm{L}^{-1}\right)$ was put onto a Pyrex glass tube and, after the mixture was degassed by three freeze-pumpthaw cycles, the tube was sealed off. The glass tube was then heated at $120^{\circ} \mathrm{C}$ for the prescribed time, and the polymerization mixture was dissolved in benzene $(5 \mathrm{~mL})$ and poured into a large excess of methanol. The polystyrene collected was purified by reprecipitation (benzene/MeOH). Conversions were determined by the weights of polystyrenes obtained, and the number average molecular weights $\left(M_{\mathrm{n}}\right)$ and polydispersity indexes $\left(M_{\mathrm{w}} / M_{\mathrm{n}}\right)$ were determined by SEC.

\section{RESULTS AND DISCUSSION}

\section{Preparation of Star-6}

Star-6 was prepared according to Scheme 1. (4Bromophenyl)alkoxyamine 1 was obtained in $88 \%$ yield by the reaction of 4-bromoethylbenzene with di-tert-butyl diperoxyoxalate in the presence of tetramethylpiperidinyl- $N$-oxyl (TEMPO). Lithiation of 1 with tert-butyllithium and subsequent reaction with DMF gave (4-formylphenyl)alkoxyamine 2 in $95 \%$ yield. Reduction of $\mathbf{2}$ with $\mathrm{NaBH}_{4}$ in methanol gave $\mathbf{3}$ in $89 \%$ yield. Bromination of $\mathbf{3}$ with $\mathrm{PBr}_{3}$ gave $\mathbf{4}$ in $67 \%$ yield as colorless needles. Reaction of 2 equiv of 4 with 3,5-dihydroxybenzyl alcohol in acetone in the presence of $\mathrm{K}_{2} \mathrm{CO}_{3}$ and 18-crown-6 gave [G-1]-OH in $67 \%$ yield as a pure colorless oil. Bromination of [G-1]-OH was carried out by treating [G-1]-OH with $\mathrm{CBr}_{4}$ and $\mathrm{PPh}_{3}$ in THF at $60^{\circ} \mathrm{C}$, and [G-1]-Br was obtained in $57 \%$ yield as a colorless oil. Reaction of 3 equiv of [G-1]-Br with 1,3,5-benzenetriol was carried out at $40{ }^{\circ} \mathrm{C}$ in acetone in the presence of $\mathrm{K}_{2} \mathrm{CO}_{3}$ and 18-crown-6. Column chromatographic purification of the reaction mixture gave a semi-solid sample of Star6 containing small amounts of impurities. Since further purification by recrystallization gave only a viscus oil, the final purification of Star-6 was performed on a preparative HPLC chromatograph. The solvent-free sample of Star-6 was obtained by freeze-drying of a benzene solution of the Star-6 (the yield for the final step 16\%).

Although the elemental analyses for [G-1]-OH and Star-6 didn't give satisfactory agreements with the calculations (see Experimental Section), ${ }^{1} \mathrm{H}$ NMR and
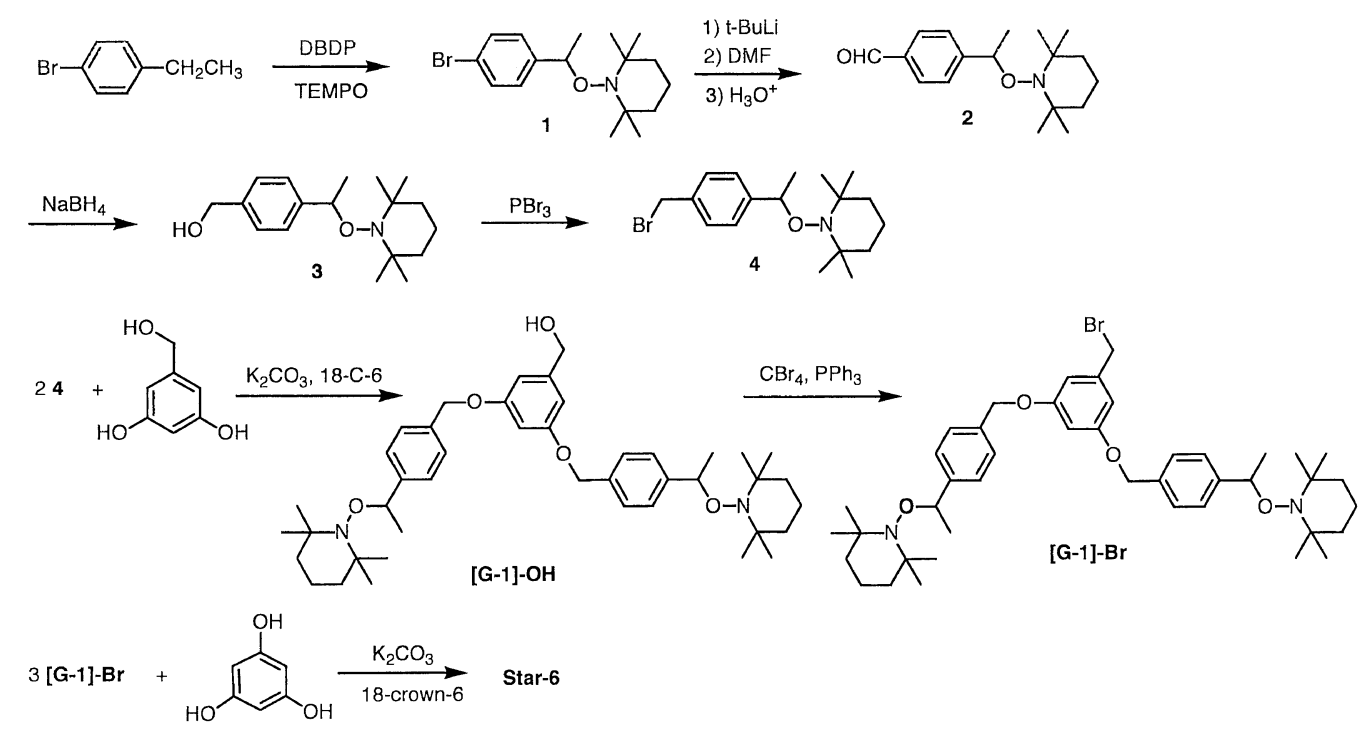

Scheme 1. 


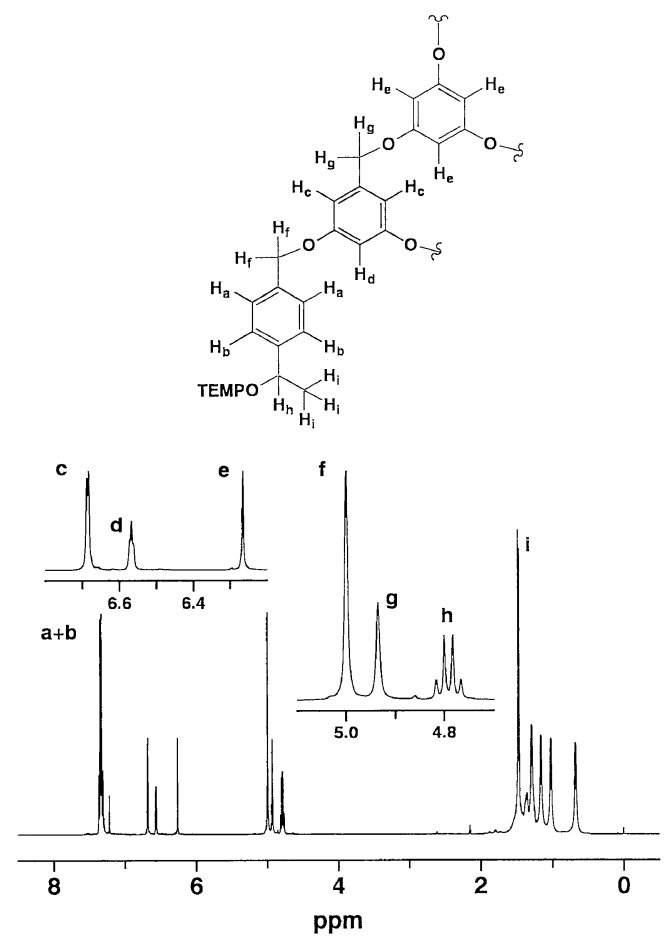

Figure 1. ${ }^{1} \mathrm{H}$ NMR spectrum $(400 \mathrm{MHz})$ of $\mathbf{S t a r}-\mathbf{6}$ in $\mathrm{CDCl}_{3}$.

high resolution mass spectra confirmed their structures. $\mathrm{A}^{1} \mathrm{H}$ NMR spectrum of Star-6 is depicted in Figure 1. The $72 \mathrm{H}$ for the 24 methyl groups at the 2 and 6 positions of the piperidine ring are observed as 4 singlets at $0.67,1.02,1.16$, and $1.29 \mathrm{ppm}$. The four singlet pattern is characteristic of TEMPO-based alkoxyamines. The doublet and quintet peaks due to $-\mathrm{CH}(\mathrm{TEMPO}) \mathrm{CH}_{3}$ are observed at $1.47\left(\mathrm{H}_{\mathrm{i}}\right)$ and $4.79 \mathrm{ppm}\left(\mathrm{H}_{\mathrm{h}}\right)$ with a coupling constant of $6.8 \mathrm{~Hz}$, respectively. The integration ratios for $\mathrm{H}_{\mathrm{i}}$ and $\mathrm{H}_{\mathrm{h}}$ revealed to correspond to $6 \mathrm{H}$ and $18 \mathrm{H}$, respectively. A singlet due to $\mathrm{H}_{\mathrm{e}}$ is observed at $6.26 \mathrm{ppm}$ with an integration ratio corresponding to $3 \mathrm{H}$. A doublet and triplet peaks due to $\mathrm{H}_{\mathrm{c}}$ and $\mathrm{H}_{\mathrm{d}}$ are observed at 6.68 and $6.56 \mathrm{ppm}$ with a coupling constant of $2.0 \mathrm{~Hz}$, and their integration ratios indicated to correspond to $6 \mathrm{H}$ and $3 \mathrm{H}$, respectively. Two singlets due to two kinds of benzylic protons, $\mathrm{H}_{\mathrm{g}}$ and $\mathrm{H}_{\mathrm{f}}$, are observed at 4.93 and $5.00 \mathrm{ppm}$ with integration ratios corresponding to $6 \mathrm{H}$ and $12 \mathrm{H}$, respectively. Accordingly, the ${ }^{1} \mathrm{H}$ NMR spectrum for Stir-6 was completely assigned. Similarly, those of [G-1]-OH and [G1]-Brwere also satisfactorily assigned.

To further confirm the structure of Star-6 and [G-1]$\mathbf{O H}$, high resolution $\mathrm{HAB}$ mass spectra (HRHABMS) were measured. In the HRHABMS of Star-6 a peak due to $[\mathrm{M}+1]^{+}$was observed at 2133.3984, which agreed with the calculation (2133.4088). Similarly, [G1]-OH gave a peak due to $[\mathrm{M}+1]^{+}$at 687.4738 , which agreed with the calculation (687.4737). On the basis of the above ${ }^{1} \mathrm{H}$ NMR and HRFABMS results, it is

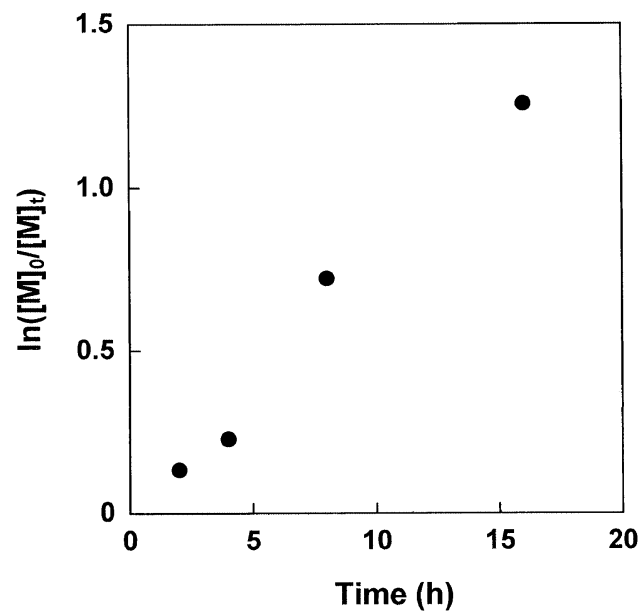

Figure 2. $\ln \left([\mathrm{M}]_{0} /[\mathrm{M}]_{\mathrm{t}}\right)$ vs. time plots for the bulk polymerization of St at $120^{\circ} \mathrm{C}$ initiated with Star-6; St $4.37 \mathrm{mmol}(0.50 \mathrm{~mL})$, [Star-6] $5.0 \mathrm{mmol} \mathrm{L}^{-1}$.

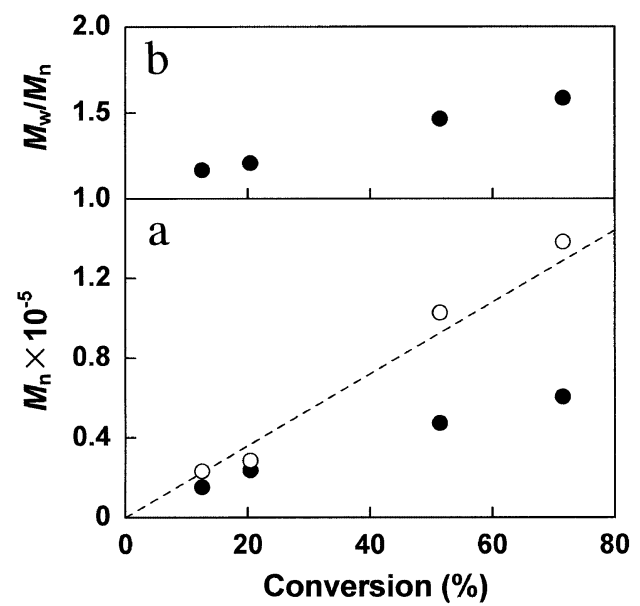

Figure 3. $M_{\mathrm{n}} v s$. conversion (a) and $M_{\mathrm{w}} / M_{\mathrm{n}}$ vs. conversion plots (b) for the bulk polymerization of St at $120^{\circ} \mathrm{C}$ initiated with Star-6. (O) Determined by SEC; $(\bigcirc)$ determined by ${ }^{1} \mathrm{H}$ NMR spectroscopy. The dotted line shows the $M_{\mathrm{n}}$ calculated by eq 1 . St $4.37 \mathrm{mmol}(0.50 \mathrm{~mL})$, Star-6 $5.0 \mathrm{mmol} \mathrm{L}^{-1}$.

concluded that Star-6 and [G-1]-OH have the desired structure.

\section{Bulk Polymerization of Styrene Initiated with Star-6}

Bulk polymerization of styrene (St) initiated with Star-6 was carried out at $120^{\circ} \mathrm{C}$ in degassed Pyrex tubes. After heating for the prescribed times, the reaction mixtures were poured into a large amount of $\mathrm{MeOH}$, and the resulting poly(St)s were collected by filtration. The polymers were purified by reprecipitation (benzene $/ \mathrm{MeOH}$ ).

In Figure $2, \ln \left([\mathrm{M}]_{0} /[\mathrm{M}]_{\mathrm{t}}\right) \mathrm{s}$ are plotted against time. A linear relationship between $\ln \left([\mathrm{M}]_{0} /[\mathrm{M}]_{\mathrm{t}}\right)$ and time is found up to a high conversion. This indicates that the number of propagating radical chains is constant during the polymerization. The $M_{\mathrm{n}} v s$. conversion and $M_{\mathrm{w}} / M_{\mathrm{n}}$ $v s$. conversion plots are depicted in Figures $3 \mathrm{a}$ and $3 \mathrm{~b}$, 
respectively. The $M_{\mathrm{n}}$ 's increase linearly with conversion up to a high conversion. However, there is a large discrepancy between the experiments and the calculations. The calculated $M_{\mathrm{n}}$ 's are derived using eq 1 .

$$
M_{\mathrm{n}}=\frac{[\mathrm{St}]_{0}}{[\mathrm{Star}-6]} \bullet M_{\mathrm{W}(\mathrm{St})} \bullet \text { conversion }+M_{\mathrm{W}(\mathrm{Star}-6)}
$$

Since star polymers have hydrodynamic volumes smaller than those of linear polymers of comparable molecular weights, this discrepancy in $M_{\mathrm{n}}$ can be explained in terms of the smaller hydrodynamic volumes. To confirm the above explanation, the $M_{\mathrm{n}}$ 's were determined by the ${ }^{1} \mathrm{H}$ NMR measurements of the star polymers obtained. A ${ }^{1} \mathrm{H}$ NMR spectrum of the star polymer at $72 \%$ conversion is depicted in Figure 4 . The aromatic protons and main chain protons are observed at $1.2-2.3$ and 6.3-7.3 ppm, respectively. Upon recording at high gain, a singlet peak due to the benzylic protons $(12 \mathrm{H}+6 \mathrm{H})$ in the Star-6 core was clearly observed at $4.91 \mathrm{ppm}$. The $M_{\mathrm{n}}$ 's of the star polymers were determined by the integration ratio of the aromatic protons to the benzylic protons. Since the Star-6 core has 36 aromatic protons corresponding to 7.2 styrene units, those protons were taken into account for the calculations of $M_{\mathrm{n}}$ by ${ }^{1} \mathrm{H}$ NMR. As found in Figure 3, the $M_{\mathrm{n}}$ 's determined by the ${ }^{1} \mathrm{H}$ NMR method are in excellent agreement with the calculations. Accordingly, it can be concluded that the low $M_{\mathrm{n}}$ 's determined by SEC can be ascribed to the smaller hydrodynamic volume of the star polymers. We furthermore determined $M_{\mathrm{w}}$ by the light scattering method. The samples measured were the star polymers at 51 and $72 \%$ conversions, and the light scattering measurements showed 93600 and 125000 as $M_{\mathrm{w}}$ for the star polymers, respectively. Since the $M_{\mathrm{n}}$ 's of the star polymers determined by the ${ }^{1} \mathrm{H}$ NMR method are 103000 and 138000 and their polydispersity indexes are 1.47 or 1.59 , the values determined by the light scattering method are much lower than the expected ones. This discrepancy in $M_{\mathrm{w}}$ may be explained in terms of the unique shape of star polymers. Further experiments will be required to clarify this point.

The polydispersity indexes $\left(M_{\mathrm{w}} / M_{\mathrm{n}}\right)$ determined by SEC at 13 and $20 \%$ conversions are 1.17 and 1.21 , respectively, indicating that the polymerization is well controlled at low conversion. However, the polydispersity index gradually increases with conversion, and at 51 and $72 \%$ conversions they were 1.47 and 1.59 , respectively. The magnitude of 1.59 is beyond the theoretical limit of 1.5 for the living polymerization. This means that the influences of side reactions disturbing the "living" fashion are no longer ignored at high conversion.

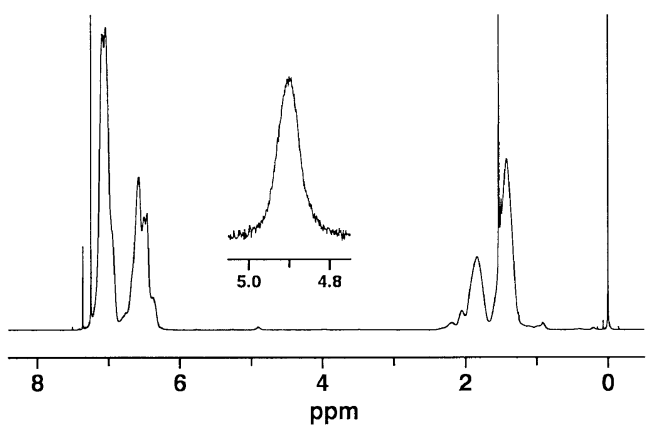

Figure 4. ${ }^{1} \mathrm{H}$ NMR spectrum $(400 \mathrm{MHz})$ of the polyer obtained by "living" radical polymerization of St at $120^{\circ} \mathrm{C}$ initiated with Star-6. Conversion $72 \%\left(M_{\mathrm{n}} 60600, M_{\mathrm{w}} / M_{\mathrm{n}} 1.59\right)$, solvent $\mathrm{CDCl}_{3}$.

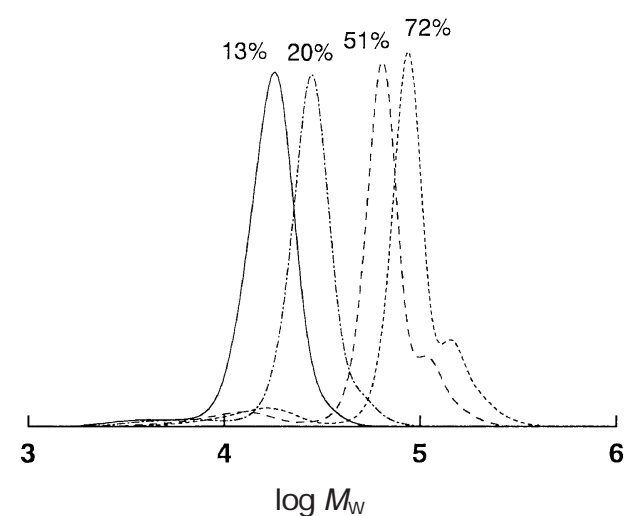

Figure 5. SEC elution curves of the star polymers at $13 \%\left(M_{\mathrm{n}}\right.$ $\left.15300, M_{\mathrm{w}} / M_{\mathrm{n}} 1.17\right), 20 \%\left(M_{\mathrm{n}} 23700, M_{\mathrm{w}} / M_{\mathrm{n}} 1.21\right), 51 \%\left(M_{\mathrm{n}}\right.$ $\left.47400, M_{\mathrm{w}} / M_{\mathrm{n}} 1.47\right)$, and $72 \%$ conversions $\left(M_{\mathrm{n}} 60600, M_{\mathrm{w}} / M_{\mathrm{n}}\right.$ $1.59)$ in the polymerization of St initiated with Star-6 in the concentration of $5.0 \mathrm{mmol} \mathrm{L}^{-1}$.

To elucidate the side reactions, the SEC elution curves were inspected. In Figure 5 the SEC elution curves are drawn. Below 20\% conversion the elution curves show an unimodal molecular weight distribution, in agreement with the low polydispersity indexes of the corresponding polymers. However, the SEC elution curves at 51 and $72 \%$ conversions are no longer an unimodal molecular weight distribution. A small peak is observed in the low molecular weight region, and a shoulder is observed at the high molecular weight region, respectively. The $M_{\mathrm{n}}$ 's for the lower molecular weight peaks at $51 \%$ and $72 \%$ conversions are 11000 and 14000 , respectively, which seem to correspond to those of linear poly(St) formed by the thermal initiation of St. On the other hand, the peak top values for the shoulders are 106000 at $51 \%$ conversion and 142000 at $72 \%$ conversion, which are approximately twice $M_{\mathrm{n}}$ 's of the main peaks ( 62000 at $51 \%$ conversion and 84000 at $72 \%$ conversion). Accordingly, it is suggested that the shoulder corresponds to the 10 arm-star polymer yielded by the star-star coupling reaction. ${ }^{14}$ Since the propagating radicals have 6 active sites per molecule, the star-star coupling reaction must occur considerably. 
Table I. Dependence of the polydispersity indexes $\left(M_{\mathrm{w}} / M_{\mathrm{n}}\right)$ on the concentrations of Star-6 in the radical polymerization of St initiated with Star-6

\begin{tabular}{cccccrr}
\hline Run & {$[$ Star-6 $] / \mathrm{mol} \mathrm{L}^{-1}$} & Conversion $/ \%$ & $M_{\mathrm{n}, \mathrm{SEC}}{ }^{\mathrm{b}}$ & $M_{\mathrm{w}} / M_{\mathrm{n}}{ }^{\mathrm{b}}$ & $M_{\mathrm{n}, \mathrm{NMR}}{ }^{\mathrm{c}}$ & $M_{\mathrm{n}, \mathrm{calc}}{ }^{\mathrm{d}}$ \\
\hline 1 & $5.0 \times 10^{-3}$ & 72 & 60600 & 1.59 & 138000 & 132000 \\
2 & $12.8 \times 10^{-3}$ & 64 & 28800 & 1.35 & 50800 & 47300 \\
3 & $18.8 \times 10^{-3}$ & 70 & 20700 & 1.29 & 34000 & 36000 \\
\hline
\end{tabular}

${ }^{\text {a St }} 4.37 \mathrm{mmol}(0.50 \mathrm{~mL})$, temperature $120^{\circ} \mathrm{C}$, time $16 \mathrm{~h} .{ }^{b}$ Determined by SEC. ${ }^{\mathrm{c}}$ Determined by ${ }^{1} \mathrm{H}$ NMR spectroscopy. ${ }^{\mathrm{d}}$ Calculated by eq 1 .

It was reported that in the nitroxide-mediated living radical polymerization of St, the polydispersity indexes of the resulting polymers decrease with an increase in the concentration of the alkoxyamine used. ${ }^{15}$ This observation suggests that the side reactions disturbing the "living" fashion are suppressed with an increase in the concentration of the alkoxyamine. We conducted the polymerizations of St using higher concentrations of Star-6 (12.8 and $\left.18.8 \mathrm{mmol} \mathrm{L}^{-1}\right)$. The concentrations of 12.8 and $18.8 \mathrm{mmol} \mathrm{L}^{-1}$ are 2.56 and 3.76 times higher than that in the polymerization described above. The results are summarized in Table I. Interestingly, when the initial concentrations of Star-6 were $12.8 \mathrm{mmol} \mathrm{L}^{-1}$, the polydispersity index of the resulting star polymer was 1.35 at $64 \%$ conversion, and when the initial concentration was $18.8 \mathrm{mmol} \mathrm{L}^{-1}$, it was 1.29 at $70 \%$ conversion. On the basis of the results we can say that, when the concentration of alkoxyamine is high enough, well-controlled star polymers can be obtained in the TEMPO-mediated "living" radical polymerization.

In Figure 6, their SEC elution curves are shown, together with that for the above star polymer. Although both the SEC elution curves still show side peaks in the lower molecular weight and higher molecular weight regions, as well as the above star polymer, such side peaks are obviously smaller than for the above star polymer. Accordingly, the undesired side reactions disturbing the "living" fashion are not completely, but considerably suppressed, well-controlled 6-arm star polymer with a low polydispersity being afforded.

\section{CONCLUSION}

A 6-arm star polymer was prepared by the nitroxidemediated "living" radical polymerization of St initiated with an dendritic TEMPO-based alkoxyamine with 6 active sites. When the polymerization of St was carried out using Star-6 of the concentration of $5.0 \mathrm{mmol}$ $\mathrm{L}^{-1}$, well-defined star polymer was obtained with a low polydispersity index below 1.3 at low conversion. At high conversions, however, the polydispersity index of the resultant star polymer was beyond 1.5 , indicating that the control of polymerization was insufficient.

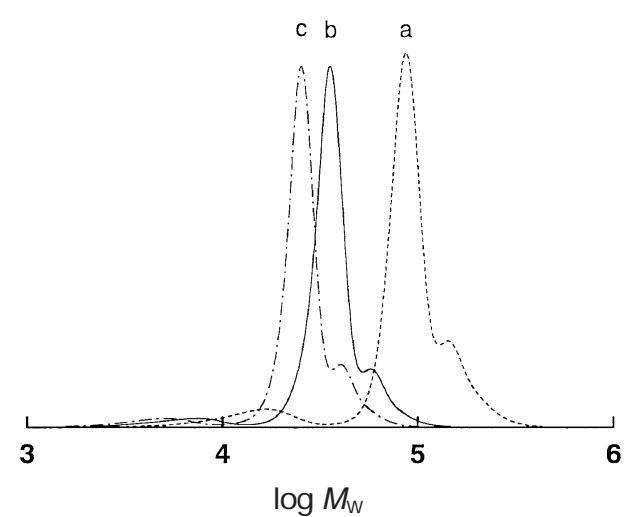

Figure 6. SEC elution curves of the star polymers:(a) Star-6 $5.0 \mathrm{mmol} \mathrm{L}^{-1}, 72 \%$ conversion $\left(M_{\mathrm{n}} 60600, M_{\mathrm{w}} / M_{\mathrm{n}} 1.59\right)$; (b) Star$612.8 \mathrm{mmol} \mathrm{L}^{-1}, 64 \%$ conversion $\left(M_{\mathrm{n}} 28800, M_{\mathrm{w}} / M_{\mathrm{n}} 1.35\right)$; (c) Star-6 $18.8 \mathrm{mmol} \mathrm{L}^{-1}, 70 \%$ conversion $\left(M_{\mathrm{n}} 20700, M_{\mathrm{w}} / M_{\mathrm{n}} 1.29\right)$.

On the other hand, when the polymerization was conducted using Star-6 of the concentration of 12.8 and $18.8 \mathrm{mmol} \mathrm{L}^{-1}$, the polymerization was well controlled and well-defined star polymer with a low polydispersity index was obtained. This result indicates that for the preparation of well-defined star polymers, particularly, in the case of high arm-numbers star polymers, the concentrations of alkoxyamines are important.

Acknowledgment. The authors would like to thank Prof. A. Matsumoto, Kansai University, for the light scattering measurements and discussion on the light scattering results. This work was financially supported in part by a Grant-in-Aid Scientific Research (No. 12450376) from the Ministry of Education, Culture, Sports, Science and Technology, Japan.

\section{REFERENCES}

1. D. H. Solomon, E. Rizzardo, and P. Cacioli, U. S. Patent 4 581429 (Apr. 8, 1986). Chem. Abstr., 102, 221335q (1985).

2. M. K. Georges, R. P. N. Veregin, P. M. Kazmaier, and G. K. Hamer, Macromolecules, 26, 2987 (1993).

3. "Controlled/Living Radical Polymerization", K. Matyjaszewski, Ed., ACS Symposium Series No. 768, American Chemical Society, Washington D.C, 2000.

4. a) C. J. Hawker, Acc. Chem. Res., 30, 373 (1997).

b) E. E. Malmström and C. J. Hawker, Macromol. Chem. 
Phys., 199, 923 (1998).

c) C. J. Hawker, A. W. Bosman, and E. Harth, Chem. Rev., 101, 3661 (2001).

5. Y. Miura and Y. Yoshida, Macromol. Chem. Phys., 203, 879 (2002).

6. a) J. Qiu and K. Matyjaszewski, Acta Polym., 48, 169 (1997). b) T. E. Patten and K. Matyjaszewski, Acc. Chem. Res., 32, 895 (1999).

c) M. Sawamoto and M. Kamigaito, Trends Polym. Sci., 4, 371 (1996).

d) M. Kamigaito, T. Ando, and M. Sawamoto, Chem. Rev., 101, 3689 (2001).

7. J. Chiefari, Y. K. Chong, F. Ercole, J. Krstina, J. Jeffery, T. P. T. Le, R. T. A. Mayadunne, G. F. Meijs, C. L. Moad, G. Moad, E. Rizzardo, and S. H. Thang, Macromolecules, 31, 5559 (1998).

8. a) S. Abrol, P. A. Kambouris, M. G. Looney, and D. H. Solomon, Macromol. Rapid Commun., 18, 755 (1997).

b) N. Ide and T. Fukuda, Macromolecules, 32, 95 (1999).

c) A. J. Pasquale and T. E. Long, J. Polym. Sci., Part A: Polym. Chem., 39, 216 (2001).

d) T. Tsoukatos, S. Pispas, and N. Hadjichristidis, J. Polym.
Sci., Part A: Polym. Chem., 39, 320 (2001).

e) A. Narumi, T. Satoh, H. Kaga, and T. Kakuchi, Macromolecules, 35, 699 (2002).

9. C. J. Hawker, Angew. Chem. Int. Ed. Eng., 34, 1456 (1995).

10. S. Robin, O. Guerret, J.-L. Couturier, and Y. Gnanou, Macromolecules, 35, 2481 (2002).

11. G. Chessa, A. Scrivanti, U. Matteoli, and V. Castelvetro, Polymer, 42, 9347 (2001).

12. P. D. Bartlett, E. P. Benzing, and R. E. Pincock, J. Am. Chem. Soc., 82, 1762 (1960).

13. a) Y. Miura, K. Hirota, H. Moto, and B. Yamada, Macromolecules, 31, 4659 (1998).

b) Y. Miura, K. Hirota, H. Moto, and B. Yamada, Macromolecules, 32, 8356 (1999).

14. a) S. Angot, K. S. Murthy, D. Taton, and Y. Gnanou, Macromolecules, 31, 7218 (1998).

b) S. Angot, K. S. Murthy, D. Taton, and Y. Gnanou, Macromolecules, 33, 7261 (2000).

15. a) Y. Miura, S. Mibae, H. Moto, N. Nakamura, and B. Yamada, Polym. Bull., 42, 17 (1999).

b) E. Drockenmuller and J.-M. Catala, Macromolecules, 35, 2461 (2002). 